\title{
THE ROLE OF CUSTOMER ENGAGEMENT IN BUILDING LOYALTY: EMPIRICAL STUDY ON BCA BANK
}

\section{Clara Uli Kumudani}

Master Program in Management

Faculty of Economics and Business

Universitas Sebelas Maret

Email: clarauli22@gmail.com

Indonesia

\section{Catur Sugiarto}

Faculty of Economics and Business

Universitas Sebelas Maret

Email: catursugiarto@staff.uns.ac.id

Indonesia

\section{ABSTRACT}

Customer loyalty is an important and strategic objective of the banking industry, which is achievable when the expectations of a product are fulfilled and satisfied. Therefore, customer satisfaction should be maintained by developing a deep interaction between customers and service providers. This study aims to analyze the effect of service quality, customer engagement, and customer satisfaction on customer loyalty at Bank Central Asia (BCA) Solo. A qualitative approach using the partial least squares structural equation modeling (PLS-SEM) was employed, to provide an insight for the marketing manager in developing strategies to increase customer loyalty. More specifically, the results showed that service quality has a positive effect on customer satisfaction, while customer satisfaction and engagement also have positive effects on customer loyalty.

\section{Keywords: Bank BCA, Customer Engagement, Service Quality, Customer satisfaction, Customer loyalty}

\section{INTRODUCTION}

The current economic development has given rise to large banks with continuously increasing competition. Government and privately-owned banks compete to attract customers by offering various products to fulfill their daily needs and providing the best services. To create customer satisfaction, firms should be able to provide the best services by improving the value of their customers. This is achievable by creating excellent products and ensuring they feel the guarantee of the offered product (Tumangkeng, 2013).

In the current development, customer satisfaction is the main criteria for assessing the relationship between customers and service providers in the banking industry. It has become a permanent object in management policy as managers became aware of its role in strengthening the firm's reputation (Munari et al., 2013). Therefore, to win in a competitive market, a firm needs to be focused on their customers, because a satisfied customer is the center of optimal performance and profit generation (Zeithaml \& Bitner, 2000). For marketing managers, customer satisfaction is an important component for a firm particularly a service company (Bennett \& Rundle-Thiele, 2004). This is because, when a customer is satisfied with a good or service, the probability of reusing increases (East, 1997).

Customers are vital assets for a firm therefore, a strategy is needed to maintain their loyalty. This also applies to https://ijbassnet.com/ a bank that needs to maintain the customer's loyalty. One way to achieve this is by providing personal services in which banks perform a series of a moment of truth for customers. Furthermore, service quality is maintained through the creation of affective, normative, and continuance commitment. Through these commitments, the bank and customer will have a long term relationship and customer's loyalty will be maintained (Afifah, 2012).

Researchers and practitioners consider customer loyalty as an important component in service company strategic goals (Keiningham et al., 2007). As one of the largest private banks in Indonesia, BCA has the vision to become a reliable bank as the community's main option and an important pillar in Indonesia's economy. To achieve this vision, it has 4 Guiding Values, which include Customer Focus, Integrity, Team Work, and Continuous Pursuit of Excellent. Furthermore, to achieve these Guiding Values, they pay close attention to customers' needs. Therefore, customer engagement becomes an important factor in the BCA strategy to achieve its goals (PT Bank Central Asia, 2018).

Specifically, a loyal customer is the main asset for a bank. Since 2012, BCA has changed its customer service (CS) transactional banking concept into relationship banking. With this change in service concept, a closer relationship with its customers is expected (Suryadi, 2016). In 2017, 17 million customer accounts were recorded, which continued to grow 
and reached 21 million in 2019. This growth showed consistency in providing services. Since BCA runs in the service industry and offers products that provide customers with experience, they will likely remember an experience when appropriate services were rendered (Soeprajitno, 2019).

This study analyzed the ability of good service quality in shaping strong customer engagement between customers and service providers and improving customer satisfaction to build customer loyalty.

\section{THEORETICAL FRAMEWORK}

\section{Service Quality}

A service firm will always pay attention to service quality or SERVQUAL dimensions. The concept of service quality developed by Parasuraman is known as the SERVQUAL dimension (service quality dimensions). It consists of five dimensions, which include 1. Tangibles or physical evidence: it is the availability of facilities and infrastructure, which includes physical facilities (building, parking area, comfortable waiting room, and other physical supporting facilities), equipment and tools used (the availability of electronic devices), neatness and employee appearance. 2. Reliability: it is the ability to provide services according to the customers' expectations accurately and trustworthily. A firm should provide timely service, minimize work errors, show sympathy, and work with a high degree of accuracy. 3. Responsiveness: it is the swiftness in delivering clear information to enable customers to access fast and precise services. Firms should provide responsive services on customers' wants and needs followed by a coherent and understandable delivery. 4. Assurance: employees can have the knowledge, politeness, and ability to develop customers' trust towards the firm. 5. Empathy: it involves the provision of individual or specific attention to customers sincerely, to understand their wishes. (Parasuraman et al., 1988)

Therefore, service quality has currently become a vital requirement for a firm in facing competitive inter-banks competition (Voss et al., 2004). Furthermore, according to Rosen, it is one of the important competitive strategies in increasing profitability and sustainability (Rosen et al., 2003).

\section{Customer Engagement}

According to Bowdwn, Customer Engagement may be defined as a psychological process in which cognitive and emotional aspect plays a different role in providing satisfaction and prompt customers to continuously use the services or products from the firm. This process shapes new customers for a service brand and is a mechanism in which loyalty is maintained for repeat purchases (Bowden, 2009). A communication or interactional relationship between customers and firms with a brand or offers or company activity outside of purchases often involves other individuals in social networks created around the brands, offers, and activities (Vivek et al., 2012).

Customer Engagement has three context-specific dimensions, which include conscious attention, enthused participation, and social connection. Conscious Attention is the level of someone's attraction or desire to own an object with real involvement. Enthused Participation is a reaction and spirit from a person who interacts with an object through an involvement. Social Connection is the increase in interaction with the object of focus, based on the inclusion of others, which in turn shows reciprocal action towards the object of focus in the presence of others (Hollebeek, 2013).

Customer Engagement has a root in the concept of involvement, which was developed from several disciplines such as psychology (Garczynski et al., 2013; Morimoto \& Friedland, 2013), organizational culture, and management (Kahn, 1990; Kataria et al., 2013; Rich et al., 2010). In marketing, it is seen as a deliberate attempt by a company to motivate, empower and measure the voluntary contribution of its customers to its marketing functions, in terms of economic transactions (Harmeling et al., 2017). In this regard, service quality becomes one of the competitive strategies for a firm to improve customer's emotional aspects. Therefore, the proposed hypothesis for this relationship is as follows:

Hı: Service quality has a positive effect on customer engagement

\section{Customer Satisfaction}

When customers perceive that their expectation is fulfilled or exceeded, they experience customer satisfaction (Gerson, 1993). According to Kotler and Armstong, customer satisfaction is a level of performance in which a product and service provided by a firm meet buyer or consumer expectations (Kotler \& Armstrong, 2004).

Therefore, based on the theories above, the emphasis on customer satisfaction lies in their expectations of a product. This is because they would be satisfied when the product meets their expectation. Furthermore, Kotler defines satisfaction as one's feeling, i.e the feeling of pleasure or disappointment received, after comparing perceived performance with expectations (Kotler \& Armstrong, 2004).

Robert W. Lucas argues that the main factor needed to maintain customer loyalty is satisfaction from the product and service provided (Lucas, 2012). This theory was interpreted as customer satisfaction becomes an important factor in building customer loyalty to continuously use the products or services provided. Therefore, a firm needs to provide optimum services and offer different characteristics from its competitors in other for the services provided to meet the customer's expectations. Customer satisfaction is the evaluation of the final score of a product or service offered by a firm in which customers' perception that the product or service selected has met or exceeded their pre-purchase expectation (Oliver, 2006). When 


\section{(C) Center for Promoting Education and Research (CPER) USA}

they feel that the service, received is lower compared to their expectation, they tend to be dissatisfied. Conversely, when the service meets their expectation, they will be satisfied and when it exceeds, they are delighted. Therefore, satisfaction is an emotional response felt by customers when they enjoy the experience of using or consuming products and services. Five dimensions of service quality developed by Parasuraman (Parasuraman et al., 1988) provide an illustration that service companies provide good quality service to their customers in other for them to have a good perception of the products and services provided (Oliver, 2006). Therefore, the hypothesized relationship is as follows:

$\mathbf{H}_{2}$ : Service quality has a positive effect on customer satisfaction

\section{Customer Loyalty}

When customers perform repurchase of goods and services, it represents their loyalty (Caruana, 2002; Gupta \& Zeithaml, 2006). Besides increasing the values in the company's business, it is used to attract new customers (Beerli et al., 2004).

Customers' decision based on self-trust without the influence of others to continuously use a service or product of a company in the long term is considered as loyalty (Lovelock \& Wright, 2002). It is interpreted as customers with high memories of other products and services, in which they would make purchases of products or services repeatedly (repeat business) and their willingness to recommend products or services to others (referral). Loyalty is considered as a positive attitude and commitment to a brand, product, or service, with the intention to continue purchase in the future (Mowen, 1998). When customers are satisfied with a product and service and they decide to make repeat purchases. Therefore, the relationship is hypothesized as follows:

$\mathbf{H}_{3}$ : Customer satisfaction has a positive effect on Customer Loyalty

\section{Customer Engagement (CE) and Customer Loyalty}

The definition of Customer Engagement from a customer's perspective is manifested as behavioral actions towards the company, which may be positive or negative (van Doorn et al., 2010). However, several studies have considered it from the company's perspective in which Customer Engagement is the manifestation of positive behavior such as working with the company (Hsieh \& Chang, 2016), liking and sharing brands on social media (Malhotra et al., 2013), as the result of a perceived relationship with the brand (Pansari \& Kumar, 2017).

The definition of customer loyalty according to Dick and Basu (Dick \& Basu, 1994) is the relationship between relative attitudes towards an entity and patronage behavior (attitude-behavior relationship). Meanwhile, according to Oliver, it is defined as a firmly held commitment to purchase or reuse preferred products or services consistently in the future. This leads to the purchasing of the same brand, regardless of situational influences and marketing efforts that potentially lead to shifting consumer behavior (Oliver, 2006).

Customer Engagement is different from loyalty, which is defined as a favorable attitude towards repeat purchases for a brand. It is an important business outcome for a company and one of the consequences of Customer Engagement (van Doorn et al., 2010). Based on the description, the proposed hypothesis is:

H4: Customer Engagement has a positive effect on Customer Loyalty.

This study focuses on customer loyalty and examines the relationship and effect of service quality on customer engagement and satisfaction. This model was adopted from several previous studies and adjusted to the current condition. The study model consists of several variables, which include service quality as an independent variable that affects the dependent variable (customer loyalty), mediated by customer engagement and customer satisfaction.

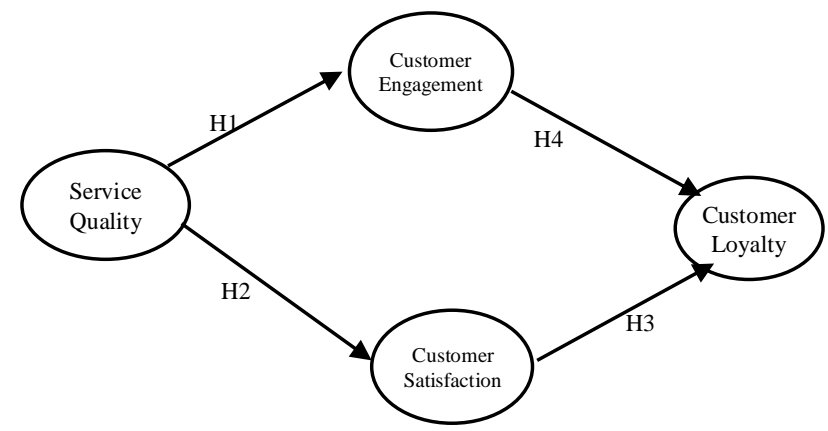

Figure 1. Research Model

\section{RESEARCH METHOD}

Design and Research Sample.

The quantitative design using Partial Least Square Structural Equation Modeling (PLS-SEM) was employed to test the instrument (outer model), structural model, and hypothesis. The target population was BCA customers actively making transactions, residing in Solo, and its ex-residency. The primary data used was obtained using an online 
questionnaire and distributed to 183 active customers actively carrying out transactions in BCA Solo. The online questionnaire was employed to save time and reach respondents in a remote area.
Respondents were identified based on several categories such as age, gender, job, educational background, and types of customers. The answers provided were arranged as seen in table 1 to provide a concise description.

Table 1. Respondent Characteristics

\begin{tabular}{llcc}
\hline & \multicolumn{1}{c}{ Characteristics } & Frequency & Percentage \\
\hline Gender & Male & 102 & 55.7 \\
\multirow{3}{*}{ Age } & Female & 81 & 44.3 \\
& 20 -30 years old & 46 & 25.1 \\
& $31-40$ years old & 36 & 19.7 \\
\multirow{4}{*}{ Latest education } & $41-50$ years old & 70 & 38.3 \\
& Older than 50 years old & 31 & 16.9 \\
& High School & 29 & 15.8 \\
Jobs & Bachelor/ Diploma & 131 & 71.6 \\
& Postgraduate & 21 & 11.5 \\
& Others & 2 & 1.5 \\
& Civil Servant/Military/Police & 3 & 1.6 \\
Types of customer & Employee & 93 & 50.8 \\
& Businessman & 67 & 36.6 \\
& Unemployed & 1 & 0.5 \\
& Others & 19 & 10.4 \\
& Credit Customer & 74 & 40.4 \\
& Funding Customer & 109 & 59.6
\end{tabular}

Based on table 1, the majority of respondents were theory of Servqual dimension from Parasuraman (Parasuraman male $(55.7 \%)$, while the rest female $(44.3 \%)$. Their age ranged et al., 1988). The measurement for customer engagement was from 20 to older than 50 years old, in which the majority was adopted from Kosiba (Kosiba et al., 2018). The question items 41-50 years old (38.3\%). Most respondents hold to measure customer satisfaction were in line with Biscaia bachelor/diploma degree (71.6\%) and mostly work as an (Biscaia et al., 2017). Lastly, customer loyalty was measured employee (50.8\%) and businessman (36.6\%). Furthermore, using question items from Nyadzayo and Khajehzadeh they were classified into two types, funding 40.4\% and credit (Nyadzayo \& Khajehzadeh, 2016). $59.6 \%$.

\section{Research Instrument.}

The instrument used in this study were 41 items consisting of $25,8,4$, and 4 items to measure service quality, customer engagement, customer satisfaction, and customer loyalty, respectively. Each question was measured using a 7points Likert scale from $1=$ strongly disagree to $7=$ strongly agree. The measurement for service quality was adopted from 25 questions used by Nyadzayo, which was in line with the

\section{DATA ANALYSIS AND DISCUSSION}

Based on the measurement analysis, all tools used met the validity and reliability criteria. All indicators in a study model are valid when it has a minimum outer loading score of 0.7. Those with an outer loading score lower than 0.7 need to be dropped from the analysis. The outer loading score is seen in Table 2. In this study model, one indicator was dropped from the analysis, SQ4.

Table 2. Outer Loading Score

\begin{tabular}{lcccc}
\hline & CE & KP & LP & SQ \\
\hline CE1 & 0.628 & & & \\
CE2 & 0.628 & & & \\
CE3 & 0.633 & & \\
CE4 & 0.612 & & \\
CE5 & 0.628 & & \\
CE6 & 0.620 & & \\
CE7 & 0.576 & & \\
CE8 & 0.593 & & \\
KP1 & & 0.651 & \\
KP2 & & 0.663
\end{tabular}




\begin{tabular}{|c|c|c|c|c|}
\hline & $\mathrm{CE}$ & KP & LP & SQ \\
\hline KP3 & & 0.665 & & \\
\hline KP4 & & 0.673 & & \\
\hline LN1 & & & 0.606 & \\
\hline LN2 & & & 0.660 & \\
\hline LN3 & & & 0.635 & \\
\hline LN4 & & & 0.661 & \\
\hline SQ1 & & & & 0.498 \\
\hline SQ10 & & & & 0.576 \\
\hline SQ11 & & & & 0.626 \\
\hline SQ12 & & & & 0.590 \\
\hline SQ13 & & & & 0.606 \\
\hline SQ14 & & & & 0.614 \\
\hline SQ15 & & & & 0.553 \\
\hline SQ16 & & & & 0.591 \\
\hline SQ17 & & & & 0.574 \\
\hline SQ18 & & & & 0.621 \\
\hline SQ19 & & & & 0.614 \\
\hline SQ2 & & & & 0.520 \\
\hline SQ20 & & & & 0.589 \\
\hline SQ21 & & & & 0.575 \\
\hline SQ22 & & & & 0.499 \\
\hline SQ23 & & & & 0.614 \\
\hline SQ24 & & & & 0.605 \\
\hline SQ25 & & & & 0.551 \\
\hline SQ3 & & & & 0.501 \\
\hline SQ5 & & & & 0.568 \\
\hline SQ6 & & & & 0.613 \\
\hline SQ7 & & & & 0.621 \\
\hline SQ8 & & & & 0.622 \\
\hline SQ9 & & & & 0.635 \\
\hline
\end{tabular}

Based on table 2, it is seen that the indicators for customer engagement have an outer loading score in the range of 0.829-0.911. Customer satisfaction has an indicator result above 0.9 . Customer loyalty has an indicator result above 0.8 and service quality has an indicator result in the range of $0.717-0.915$. This explains that the collected data were valid.
In addition to a minimum outer loading of 0.7 , SEM also requires study variables to pass the convergent and discriminant validity test. Convergent validity is fulfilled when the minimum Average Variance Extracted (AVE) score is 0.5. The result of the Average Variance Extracted analysis is presented in Table 3.

\section{Table 3. Convergent Validity Testing}

\begin{tabular}{cc}
\hline & Average Variance Extracted (AVE) \\
$\mathrm{CE}$ & 0.785 \\
$\mathrm{KP}$ & 0.911 \\
$\mathrm{LP}$ & 0.853 \\
$\mathrm{SQ}$ & 0.707 \\
\hline \multicolumn{2}{c}{ Source: Processed primary data (2020) }
\end{tabular}


In this study, the AVE score of customer engagement, correlation from all indicators in a construct. The acceptable satisfaction, loyalty, and service quality was $0.785,0.911$, score for this test is under 0.90 . The result of discriminant 0.853 , and 0.707 , respectively. Therefore, the result of the validity testing using the HTMT score is summarized in Table AVE test was accepted.

The discriminant validity is seen from the HeterotraitMonotrait (HTMT). The HTMT criteria measure the average

Table 4. Nilai HTMT

\begin{tabular}{ccccc}
\hline & CE & KP & LP & SQ \\
\hline CE & & & \\
KP & 0.942 & & \\
LP & 0.951 & 0.921 & & \\
SQ & 0.917 & 0.951 & 0.876 & \\
\hline \multicolumn{5}{c}{ Source: Processed primary data (2020) }
\end{tabular}

Based on Tables 2, 3, and 4 it was concluded that the The minimum required score for Cronbach's Alpha and convergent and discriminant validity in this study were Composite Reliability (CR) is 0.7, while the minimum score fulfilled.

for AVE (Average Variance Extracted) is 0.5. The result of the The reliability analysis in SmartPLS was carried using reliability test using these two methods is summarized in Table two methods, Cronbach's Alpha and Composite Reliability. 5.

Table 5. The Result of Reliability Test

\begin{tabular}{cccl}
\hline & Cronbach's Alpha & $\begin{array}{l}\text { Composite } \\
\text { Reliability }\end{array}$ & $\begin{array}{l}\text { Average } \\
\text { Variance } \\
\text { Extracted (AVE) }\end{array}$ \\
\hline CE & 0.961 & 0.967 & 0.785 \\
KP & 0.967 & 0.976 & 0.911 \\
LP & 0.942 & 0.959 & 0.853 \\
SQ & 0.982 & 0.983 & 0.696 \\
\hline \multicolumn{4}{l}{ Source: Processed primary data (2020) }
\end{tabular}

Based on the results presented in Table 5, it was concluded that the reliability requirement was met, in which the result of Cronbach's Alpha for CE, KP, LP, and SQ was $0.961,0.967,0.942$, and 0.982 , respectively. Meanwhile, the composite reliability score for CE, KP, LP, and SQ was 0.967, $0.976,0.959$, and 0.983 , respectively. Therefore, with the fulfillment of validity and reliability requirements, the analysis was continued to the hypothesis testing.

Table 6. The Result of Hypothesis Testing

\begin{tabular}{cccccc}
\hline & Original Sample (O) & Sample Mean (M) & $\begin{array}{c}\text { Standard Deviation } \\
(\text { STDEV })\end{array}$ & $\begin{array}{c}\text { T Statistics } \\
(\mid \text { O/STDEV } \mid)\end{array}$ & P values \\
\hline SQ -> CE & 0.892 & 0.888 & 0.032 & 27.783 & 0.000 \\
SQ -> KP & 0.928 & 0.925 & 0.022 & 41.879 & 0.000 \\
CE -> LN & 0.595 & 0.597 & 0.120 & 4.975 & 0.000 \\
KP -> LN & 0.343 & 0.338 & 0.120 & 2.861 & 0.004 \\
\hline
\end{tabular}

Source: Processed primary data (2020)

The independent variables have a significant effect on the dependent variable when the p-value is lower than 0.05 . The direction of the influence in this path is shown in the positive or negative value of the original sample value.

Hypothesis $1(\mathrm{Hl})$ : service quality has a positive effect on customer engagement. Based on Table 6 , it is seen that the relationship between service quality (SQ) and customer

engagement (CE) was a p-value of 0.000 and an original sample score of 0.892 . This implies that service quality has a significant and positive effect on customer engagement. This discovery was in line with the Voss statement that service quality is an important requirement when a company is facing overly competitive interbank competition (Voss et al., 2004). Therefore, it is one of the competitive strategies (Rosen et al., 


\section{CCenter for Promoting Education and Research (CPER) USA}

WWW.cpernet.org

2003) needed to increase a firm's profitability and sustainability.

Hypothesis 2 (H2): service quality has a positive effect on customer satisfaction. Based on Table 6, it was seen that the relationship between service quality (SQ) and customer satisfaction (KP) has a p-value of 0.000 and an original sample score of 0.928 . This implies that service quality has a positive and significant effect on customer satisfaction. Parasuraman in service quality dimensions (Parasuraman et al., 1988) describes that service companies will provide good services to their customers, therefore, developing a positive image toward the products and services (Oliver, 2006).

Hypothesis 3 (H3): customer satisfaction has a positive effect on customer loyalty. Based on Table 6, it was seen that the relationship between customer satisfaction (KP) and customer loyalty (LP) has a p-value of 0.000 and an original sample score of 0.595 . This implies that customer satisfaction has a positive and significant effect on customer loyalty. Customer satisfaction marked with repeat purchases or business and willingness to recommend products and services to others (referral), is defined as customer loyalty to a product or services. Loyalty is also developed from customers' memory of certain product or services including positive attitude toward and commitment towards a brand, product, or service and intends to continue the purchase in the future (Mowen, 1998)

Hypothesis 4 (H4): Customer engagement has a positive effect on Customer Loyalty. Based on Table 6, it is seen that the relationship between customer engagement (CE) and customer loyalty (LP) has a p-value of 0.004 and an original sample score of 0.343 . This implies that customer engagement has a positive and significant effect on customer loyalty. This was in line with the Bowden statement that customer engagement may be defined as a psychological process in which the cognitive and emotional aspects of the concept of engagement play different roles in a process that brings satisfaction. Consequently, the customer will continue using company product or service and in turn form new customers for service brands and a mechanism in which loyalty may be maintained for repeat purchases for a service brand (Bowden, 2009).

\section{b. Direct Effect}

The level of influence of the independent variable on the dependent variable was seen from the R square score. The $\mathrm{R}$ square is shown in Table 7.

Table 7. R Square

\begin{tabular}{lcc}
\hline & R Square & R Square Adjusted \\
\hline $\mathrm{CE}$ & 0.796 & 0.795 \\
$\mathrm{SQ}$ & 0.861 & 0.860 \\
$\mathrm{KP}$ & 0.841 & 0.839 \\
\hline & \multicolumn{2}{c}{ Source: Processed primary data (2020) }
\end{tabular}

Based on Table 7, it is seen that the effect of service quality on customer engagement was 0.796 . This implies that service quality affects $79.6 \%$ of the variability in customer engagement. Meanwhile, the rest were affected by other variables outside the study. The $86.1 \%$ variation in customer satisfaction was affected by service quality, while the combination of service quality, customer engagement, and customer satisfaction contributed $84.1 \%$ of the variability in customer loyalty.

c. Indirect Effect. There are two mediating variables in this study which aims to examine the indirect effect of the independent variables on the dependent variable. The result of an indirect effect analysis is summarized in Table 8 .

Table 8. Indirect Effect

\begin{tabular}{cccccc}
\hline & $\begin{array}{c}\text { Original Sample } \\
(\mathrm{O})\end{array}$ & $\begin{array}{c}\text { Sample } \\
\text { Mean }(\mathrm{M})\end{array}$ & $\begin{array}{c}\text { Standard Deviation } \\
(\text { STDEV })\end{array}$ & $\begin{array}{c}\text { T Statistics } \\
(|\mathrm{O} / \mathrm{STDEV}|)\end{array}$ & P values \\
\hline SQ -> CE -> LN & 0.530 & 0.531 & 0.110 & 4.810 & 0.000 \\
SQ -> KP -> LN & 0.318 & 0.313 & 0.111 & 2.853 & 0.005 \\
\hline Source? Processed primary data $(2020)$ & &
\end{tabular}

Source: Processed primary data (2020)

Based on the data in Table 8, two indirect mediations, which include service quality and customer satisfaction, mediated by customer engagement have a significant effect on customer loyalty, as shown by the p-value of 0.000 and 0.005 , respectively, which are lower than 0.05 .

\section{CONCLUSION AND SUGGESTIONS}

This study aims to examine the effect of service quality, customer engagement, and customer satisfaction on customer loyalty in BCA Solo. The data used was obtained by distributing a questionnaire to BCA customers in Solo and its ex-residence regions. Afterward, data analysis was carried out using PLS-SEM software.

Based on the analysis, it was concluded that there is a positive and significant relationship on 1 . Service quality and customer engagement, 2. Service quality and customer satisfaction, 3. Customer engagement and customer loyalty and 4. Customer satisfaction and customer loyalty. A positive and 
significant relationship indicates that there is a causality relationship between the variables.

The analysis result on the mediating variables showed an indirect effect in which service quality mediated by customer engagement and satisfaction had significant effects on customer loyalty.

However, this study has several limitations, because an online questionnaire was used to collect the data due to the Covid-19 pandemic. This method has limitations since not all customers understand the instructions in the questionnaire which leads to errors in data entry or incomplete data. There is also the limitation of internet connection which makes it difficult for customers leading to incomplete filling of the questionnaire. Furthermore, this study only met the minimum standard of sample size for PLS-SEM analysis. Therefore, for future studies, it is suggested that data should be collected from a greater number of respondents.

\section{REFERENCES}

Afifah, N. (2012). Pengaruh Kualitas Layanan Terhadap Komitmen Afektif, Komitmen Normatif, Komitmen Kontinuan Serta Loyalitas Nasabah Debitur Pada PT Bank Kalbar di Kalimantan Barat. 2, 16.

Beerli, A., Martín, J. D., \& Quintana, A. (2004). A model of customer loyalty in the retail banking market. European Journal of Marketing, 38(1/2), 253-275. https://doi.org/10.1108/03090560410511221

Bennett, R., \& Rundle-Thiele, S. (2004). Customer satisfaction should not be the only goal. Journal of Services Marketing, 18(7), 514-523. https://doi.org/10.1108/08876040410561848

Bowden, J. L.-H. (2009). The Process of Customer Engagement: A Conceptual Framework. Journal of Marketing Theory and Practice, 17(1), 63-74. https://doi.org/10.2753/MTP1069-6679170105

Caruana, A. (2002). Service loyalty. European Journal of Marketing.

Dick, A. S., \& Basu, K. (1994). Customer Loyalty: Toward an Integrated Conceptual Framework. Journal of the Academy of Marketing Science, 22(2), 99-113. https://doi.org/10.1177/0092070394222001

East. (1997). Customer Satisfaction Indicators (4th ed.). Britain: Oxford University Press.

Garczynski, A. M., Waldrop, J. S., Rupprecht, E. A., \& Grawitch, M. J. (2013). Differentiation between work and nonwork selfaspects as a predictor of presenteeism and engagement: Cross-cultural differences. Journal of Occupational Health Psychology, 18(4), 417-429. https://doi.org/10.1037/a0033988

Gerson, R. (1993). Measuring customer satisfaction (Paperback). Crisp Learning.

Gupta, S., \& Zeithaml, V. (2006). Customer Metrics and Their Impact on Financial Performance. Marketing Science, 25(6), 718-739. https://doi.org/10.1287/mksc.1060.0221

Harmeling, C. M., Moffett, J. W., Arnold, M. J., \& Carlson, B. D. (2017). Toward a theory of customer engagement marketing. Journal of the Academy of Marketing Science, 45(3), 312-335. https://doi.org/10.1007/s11747-016-0509-2

Hollebeek, L. D. (2013). The customer engagement/value interface: An exploratory investigation. Australasian Marketing Journal (AMJ), 21(1), 17-24. https://doi.org/10.1016/j.ausmj.2012.08.006

Hsieh, S. H., \& Chang, A. (2016). The Psychological Mechanism of Brand Co-creation Engagement. Journal of Interactive Marketing, 33, 13-26. https://doi.org/10.1016/j.intmar.2015.10.001

Kahn, W. A. (1990). Psychological Conditions of Personal Engagement and Disengagement at Work. Academy of Management Journal, 33(4), 692-724. https://doi.org/10.5465/256287

Kataria, A., Rastogi, R., \& Garg, P. (2013). Organizational Effectiveness as a Function of Employee Engagement. 4, 19.

Keiningham, T. L., Cooil, B., Aksoy, L., Andreassen, T. W., \& Weiner, J. (2007). The value of different customer satisfaction and loyalty metrics in predicting customer retention, recommendation, and share-of-wallet. Managing Service Quality: An International Journal, 17(4), 361-384. https://doi.org/10.1108/09604520710760526

Kotler, philip, \& Armstrong, G. (2004). Principles of Marketing. Pearson Education Inc.

Lovelock, C., \& Wright, L. (2002). Principles of Service Marketing and Management, Prentice Hall, New Jersey.

Lucas, R. W. (2012). Customer Service-Building Successful Skills for the Twenty First Century-ProQuest. https://search.proquest.com/openview/6575e959258c4cdea210eb484a31e8a7/1?pq-origsite=gscholar\&cbl=546310 
Malhotra, A., Malhotra, C. K., \& See, A. (2013). How to create brand engagement on Facebook. MIT Sloan Management Review, 54(2), 18-20.

Morimoto, S. A., \& Friedland, L. A. (2013). Cultivating Success: Youth Achievement, Capital and Civic Engagement in the Contemporary United States. Sociological Perspectives, 56(4), 523-546. https://doi.org/10.1525/sop.2013.56.4.523

Mowen, J. C. (1998). Minor. M.(1998)“Consumer Behavior.” New York: Prentice Hall Inc.

Munari, L., Ielasi, F., \& Bajetta, L. (2013). Customer satisfaction management in Italian banks. Qualitative Research in Financial Markets, 5(2), 139-160. https://doi.org/10.1108/QRFM-11-2011-0028

Nyadzayo, M. W., \& Khajehzadeh, S. (2016). The antecedents of customer loyalty: A moderated mediation model of customer relationship management quality and brand image. Journal of Retailing and Consumer Services, 30, $262-270$. https://doi.org/10.1016/j.jretconser.2016.02.002

Oliver, R. L. (2006). Customer Satisfaction Research. In R. Grover \& M. Vriens, The Handbook of Marketing Research (pp. 569-587). SAGE Publications, Inc. https://doi.org/10.4135/9781412973380.n27

Pansari, A., \& Kumar, V. (2017). Customer engagement: The construct, antecedents, and consequences. Journal of the Academy of Marketing Science, 45(3), 294-311. https://doi.org/10.1007/s11747-016-0485-6

Parasuraman, A., Zeithaml, V. A., \& Berry, L. L. (1988). Servqual: A Multiple-Item Scale For Measuring Consumer Perc ProQuest.

origsite $=$ gscholar

PT Bank Central Asia. (2018). Annual Report BCA.

Rich, B. L., Lepine, J. A., \& Crawford, E. R. (2010). Job Engagement: Antecedents and Effects on Job Performance. Academy of Management Journal, 53(3), 617-635. https://doi.org/10.5465/amj.2010.51468988

Rosen, L. D., Karwan, K. R., \& Scribner, L. L. (2003). Service quality measurement and the disconfirmation model: Taking care in interpretation. Total Quality Management \& Business Excellence, 14(1), 3-14. https://doi.org/10.1080/14783360309703

Soeprajitno, H. (2019, December 4). Armand W. Hartono, Marketeer of the Year 2019. Marketeers - Majalah Bisnis \& Marketing Online - Marketeers.Com. https://marketeers.com/armand-w-hartono-marketeer-of-the-year-2019/

Suryadi, D. (2016, July 2). Beginilah Strategi BCA Menjadi Relationship Banking. SWA.Co.Id. https://swa.co.id/swa/trends/marketing/beginilah-strategi-bca-menjadi-relationship-banking

Tumangkeng, G. A. (2013). KUALITAS PRODUK, SUKU BUNGA DAN KUALITAS PELAYANAN PENGARUHNYA TERHADAP KEPUASAN PELANGGAN KPR BANK BTN CABANG MANADO. 1, 78-85.

van Doorn, J., Lemon, K. N., Mittal, V., Nass, S., Pick, D., Pirner, P., \& Verhoef, P. C. (2010). Customer Engagement Behavior: Theoretical Foundations and Research Directions. Journal of Service Research, 13(3), 253-266. https://doi.org/10.1177/1094670510375599

Vivek, S. D., Beatty, S. E., \& Morgan, R. M. (2012). Customer Engagement: Exploring Customer Relationships Beyond Purchase. Journal of Marketing Theory and Practice, 20(2), 122-146. https://doi.org/10.2753/MTP1069-6679200201

Voss, C. A., Roth, A. V., Rosenzweig, E. D., Blackmon, K., \& Chase, R. B. (2004). A Tale of Two Countries' Conservatism, Service Quality, and Feedback on Customer Satisfaction. Journal of Service Research, 6(3), 212-230. https://doi.org/10.1177/1094670503260120

Zeithaml, V. A., \& Bitner, M. J. (2000). Service Marketing: Integrating Customer Focus accross the Firm (International, Vol. 12nd edition). 